\title{
Physicochemical, Nutritional and Functional Properties of the Epicarp, Flesh and Pitted Sample of Doum Fruit (Hyphaene Thebaica)
}

\author{
Waleed Aboshora ${ }^{1,3,4}$, Zhang Lianfu ${ }^{1,2,3, *}$, Mohammed Dahir ${ }^{1}$, Mohammed A.A Gasmalla ${ }^{1}$, Abubakr Musa ${ }^{1}$, \\ Elshareif Omer $^{1}$, Mallika Thapa ${ }^{1}$ \\ ${ }^{1}$ State Key Laboratory of Food Science and Technology, Jiangnan University, Wuxi, 214122, China \\ ${ }^{2}$ School of Food Science and Technology, Jiangnan University, Wuxi, 214122, China \\ ${ }^{3}$ National Engineering Research Center for Functional Food, Jiangnan University, Wuxi, 214122, China \\ ${ }^{4}$ Department of Food Processing, Faculty of Engineering, University of Elemam Elmahadi, P. O. Box 209, Kosti, Sudan \\ *Corresponding author: lianfu@jiangnan.edu.cn
}

Received April 12, 2014; Revised May 10, 2014; Accepted May 12, 2014

\begin{abstract}
In this study, the physicochemical, nutritional and functional properties of epicarp, flesh and pitted samples of doum fruit (Hyphaene thebaica) were assessed. Results on carbohydrate content revealed that the flesh, pitted fruit and epicarp samples contained $72.50 \%, 65.61 \%$ and $44.17 \%$ respectively. Total fiber was highly concentrated in the epicarp accounting for more than $40 \%$. It was further revealed that the fruit contained substantial amounts of essential minerals as follows: sodium $364.7 \mathrm{mg} / 100 \mathrm{~g}$, calcium $284 \mathrm{mg} / 100 \mathrm{~g}$ and iron $12.18 \mathrm{mg} / 100 \mathrm{~g}$ in the epicarp while the following were contained in the flesh part of the fruit: potassium $2947.6 \mathrm{mg} / 100 \mathrm{~g}$, magnesium $185.62 \mathrm{mg} / 100 \mathrm{~g}$ and phosphorus $154.6 \mathrm{mg} / 100 \mathrm{~g}$. Vitamin content was determined by RP-HPLC and the results showed that doum fruit is a good source of vitamin B-complex which was found it at high portion in epicarp with the variance of $3.6 \mathrm{mg} / 100 \mathrm{~g}$ in niacin (B3) content to $13.6 \mathrm{mg} / 100 \mathrm{~g}$ in pyridoxine (B6) content. Monosaccharide content was determined by using HPAEC-PAD and the results showed that the flesh of the doum fruit is a good source of glucose and fructose. There was a significant difference in color parameters between samples. Bulk density results were $0.73,0.75$ and $0.95 \mathrm{mg} / \mathrm{ml}$ for epicarp, pitted fruit and flesh respectively. It can be concluded that the doum fruit contained essential nutrients and functional properties which can be exploited for various useful applications.
\end{abstract}

Keywords: doum fruit (Hyphaene thebaica), epicarp, flesh, pitted fruit, Physicochemical, nutritional, functional properties

Cite This Article: Waleed Aboshora, Zhang Lianfu, Mohammed Dahir, Mohammed A.A Gasmalla, Abubakr Musa, Elshareif Omer, and Mallika Thapa, "Physicochemical, Nutritional and Functional Properties of the Epicarp, Flesh and Pitted Sample of Doum Fruit (Hyphaene Thebaica).” Journal of Food and Nutrition Research vol. 2, no. 4 (2014): 180-186. doi: 10.12691/jfnr-2-4-8.

\section{Introduction}

Doum palm (Hyphaene thebaica) is a desert palm native to Egypt, sub-Saharan Africa and West India. It is known in Egypt as the doum or gingerbread palm which grows to a height of 6 or $9 \mathrm{~m}$ and usually has forked stems with fan shaped leaves, $65-75 \mathrm{~cm}$ long. It is listed as one of the useful plants of the world [1]. The trunk of the palm is used for construction, as well as for manufacture of various domestic utensils and the leaves used to make mats, bind parcels and writing paper. The oblong, yelloworange apple sized fruit has a red outer skin, a thick, spongy and rather sweet, fibrous fruit pulp that tastes like gingerbread and a large kernel. The covering of the fruit is edible and can either be pounded to form a powder or cut off in slices; the powder is often dried then added to food as a flavouring agent [2]. The fruit pulp is used in cooking, in various ways, and the different varieties differ in their edibility. While the unripe kernel is edible, the ripe kernel is hard and used only as a vegetable ivory [3]. Previous studies on Doum had focused on the fruit because, besides its nutritional value, the fruit drink brewed from a hot water infusion of the dried fruit pulp is widely consumed as a health tonic and has been valued in the region for its many anecdotal medicinal properties. Research on the fruit pulp of $\mathrm{H}$. thebaica showed that it contains nutritional trace minerals, proteins and fatty acids, in particular the nutritionally essential linoleic acid [4]. Also, the aqueous extract of doum fruits showed an antioxidant and anticancer activities; this is due to the substantial amount of their water-soluble phenolic contents $[5,6]$. The doum palm is among the more important plant families that supplies human with dietary fibers, carbohydrates and anti-hypertension substances. The phytochemical, called lignans, having apparent anti-carcinogenic action as mentioned by Carter [7]. The aqueous extract of the doum 
fruits revealed an antifungal activity against a wide range of fungal isolates. Also, prominent antibacterial activities of doum fruits were reported against gram positive and gram negative bacteria [8]. Essential minerals are sometimes divided up into major minerals (macrominerals) and trace minerals (microminerals). These two groups of minerals are equally important, but trace minerals are needed in smaller amounts than major minerals. The amounts needed in the body are not an indication of their importance. The biochemical functions of trace elements appear to be as components of prosthetic groups or as cofactors for enzymes. Deficiency syndromes for several of the essential trace elements were not recognized until recently because of their exceedingly small requirements and because of the ubiquitous nature of these elements in foodstuffs [9]. Vitamins are organic substances present in minute amounts in foodstuffs and necessary for metabolism. They are grouped together not because they are chemically related or have similar physiological functions, but because, as their name implies, they are vital factors in the diet and because they were all discovered in connection with the diseases resulting from their deficiency [10]. The simplest carbohydrates are the monosaccharides, or simple sugars. These sugars can pass through the wall of the alimentary tract without being changed by the digestive enzymes [10]. The color of dried products is an important quality factor which reflects the sensory attractiveness and the quality of the powder. Though a functional food could provide several health benefits to consumers, without visual attraction to the consumers it cannot be marketable. Thus, the color of the supplemented products should ideally remain unchanged after production [11]. The objective of this study is to compare the physiochemical, nutritional and functional properties of epicarp, flesh and pitted sample of Doum fruit (Hyphaene thebaica). Furthermore, this study is aimed at assessing the colour characteristics, bulk density and the functional properties of the different parts of the doum fruit namely the epicarp, flesh and the pitted fruit. Absence of previous studies on nutritional values, color parameters and functional properties of epicarp, flesh and pitted of Doum fruit (Hyphaene thebaica) makes this study the first trial to be conducted in our research interest.

\section{Materials and Methods}

\subsection{Materials}

The doum fruit was collected from Tayba Garden in Elgazira Aba city, Republic of Sudan. The collected samples were divided into two groups, where the first group was peeled and extracted the flesh from the rest of the fruit, and then sun dried separately, while the second group was pitted (seeds were removed) and the rest of the fruit was sun dried. Pre-dried Doum fruit samples were brought to the National Engineering Research Center for Functional Food, Jiangnan University, Wuxi. P.R of China. The samples were kept dry at room temperature in desiccators and then milled using a laboratory scale hammer mill (Debarker Co. Ltd., Beijing, China).

Analytical reagents and HPLC-grade solvents were obtained from Sinopharm Chemical Reagent Co. Ltd., Shanghai, China.

\subsection{Proximate Analysis}

The flesh, epicarp and pitted sample of doum fruit were analyzed separately. The total protein content was evaluated using a FOSS nitrogen analyzer (DK-3400 Hilleroed, Denmark) with a conversion factor of 6.25. Fat, moisture, fiber and ash contents were determined using standard AOAC methods 932.06, 925.09, 985.29 and 923.03 respectively [12]. The carbohydrate content was determined by difference. Energy values were calculated from the data on protein, carbohydrates and fats by means of factors of 4, 4 and $9 \mathrm{kcal} / \mathrm{g}$, respectively [13].

\subsection{Determination of Mineral Elements}

Mineral composition in the samples was determined from the ash which was prepared and dissolved in $10 \mathrm{~mL}$ of concentrated $\mathrm{HNO}_{3}$ and made up to $25 \mathrm{~mL}$. Calcium content was estimated by the titrimetric method. Iron content was estimated by using a UV-Visible spectrophotometer (model UV-160A, Shimadzu, Shanghai, China) at $480 \mathrm{~nm}$ [14]. Magnesium was analyzed by Ranganna method [15]. The blue color that developed was measured at $650 \mathrm{~nm}$ in a UV-Visible spectrophotometer (model UV-160A, Shimadzu). Other minerals were estimated by atomic absorption spectroscopy (Shimadzu AA 6701F, Atomic Absorption Flame Emission Spectrophotometer equipped with hollow cathode lamps).

\subsection{Analysis of Vitamins by HPLC}

The quantitative vitamin contents of doum fruit samples were determined by reversed-phase high-performance liquid chromatography (RP-HPLC) system (Agileat 1100, USA) according to the method of [16] with some modification. The ground sample $(0.5 \mathrm{~g})$ was macerated in a glass blender containing $5 \mathrm{~mL} \mathrm{30 \%} \mathrm{metaphosphate.} \mathrm{The}$ macerate was diluted to $25 \mathrm{~mL}$ in a graduated flask with distilled water. The diluted solution was then filtered through a $0.45 \mu \mathrm{m}$ filter. The filtrate was then injected directly into the HPLC with the injection volume $10 \mu \mathrm{l}$, column (Dimonsil C18 5u 250×4.6 mm) temperature $30^{\circ} \mathrm{C}$, flow rate $(0.8 \mathrm{ml} / \mathrm{min})$, detector (Ultraviolet detector 254 $\mathrm{nm}, 280 \mathrm{~nm}$ ) and a mobile phase of sodium 1heptanesulfonate $0.05 \mathrm{M}$ and methanol at different time intervals 0,20 and $25 \mathrm{~min}$ in a ratio of 90:10, 30:70 and 30:70, respectively.

\subsection{Monosaccharides Analysis}

The monosaccharide compositions of doum fruit samples was determined as described by [17] with slight modifications. The samples were digested in $1 \mathrm{M} \mathrm{H}_{2} \mathrm{SO}_{4}$ at $100^{\circ} \mathrm{C}$ for $2 \mathrm{~h}$ and diluted 50 times. The diluted samples were passed through a $0.45 \mu \mathrm{m}$ filter and injected to the high performance anion exchange chromatography with pulsed amperometric detection (HPAEC-PAD) (ICS-5000, Dionex Corporation, USA), equipped with a CarboPac ${ }^{\mathrm{TM}}$ PA20 column (250-4 mm I.D., Dionex Corporation, USA) and a guard column (3 - 25 mm, Dionex Corporation, Canada). Separations were achieved with isocratic elution (250 $\mathrm{mM} \mathrm{NaOH})$ at a flow rate of $0.5 \mathrm{ml} / \mathrm{min}$. A postcolumn delivery solvent system of 5 and $20 \%$ of $1 \mathrm{M}$ $\mathrm{NaAc}$ was added to the HPAEC-PAD system after 21 and $30 \mathrm{~min}$, respectively, at a flow rate of $0.5 \mathrm{ml} / \mathrm{min}$. The 
amount of total sugar in different fractions was taken as the sum of the monosaccharides in each fraction.

\subsection{Color Parameters}

A Hunter Lab digital colorimeter (TC-PIIG system, Beijing Optical Instrument Co. Ltd., Beijing, China) was used to measure the color of selected doum fruit samples and color scales $\mathrm{L}^{*} \mathrm{a}^{*} \mathrm{~b} *$ values were recorded. A cylindrical plastic dish (58 mm in diameter and $15 \mathrm{~mm}$ in depth) containing the same quantity of samples was placed at the light port (50 $\mathrm{mm}$ in diameter). The instrument was initially calibrated with a white standard plate $\left(\mathrm{L}^{*}=99.50\right.$, $\left.a^{*}=-0.06, b^{*}=-0.19\right)$. The samples values $L^{*}, a^{*}$ and $b^{*}$ were read and printed out directly by the TC-PIIG automatic color difference meter and using the color difference indicator of $\Delta \mathrm{L}^{*}, \Delta \mathrm{a}^{*}, \Delta \mathrm{b}^{*}$ and $\Delta \mathrm{E}$, representing the lightness - darkness $\left(\Delta \mathrm{L}^{*}\right)$, redness greenness $\left(\Delta \mathrm{a}^{*}\right)$, yellowness - blueness $\left(\Delta \mathrm{b}^{*}\right)$ and total color difference $(\Delta \mathrm{E})$. The indicators were calculated as follows:

$$
\begin{aligned}
& \Delta \mathrm{L}^{*}=\mathrm{L}_{\text {sample }}^{*}-\mathrm{L}_{\text {standard }}^{*} ; \\
& \Delta \mathrm{a}^{*}=\mathrm{a}_{\text {sample }}^{*}-\mathrm{a}_{\text {standard }}^{*} ; \\
& \Delta \mathrm{b}^{*}=\mathrm{b}_{\text {sample }}^{*}-\mathrm{b}_{\text {standard }}^{*} ; \\
& \Delta \mathrm{E}=\sqrt{\left(\Delta \mathrm{L}^{* 2}+\Delta \mathrm{a}^{* 2}+\Delta \mathrm{b}^{* 2}\right) .}
\end{aligned}
$$

\subsection{Bulk Density}

Bulk density of samples was determined by the method suggested by [18]. In this method the flour samples were gently filled into $10 \mathrm{ml}$ graduated cylinders, previously tarred. The bottom of each cylinder was tapped until there was no further diminution of the sample level after filling to the $10 \mathrm{ml}$ mark. Bulk density was calculated as weight of sample per unit volume of sample $(\mathrm{g} / \mathrm{ml})$.

\subsection{Determination of Functional Properties}

The functional properties; water and oil absorption capacities (1 g sample); wettability capacity (1 g sample) and gelatinization point (10 g sample) were measured using method described by [19].

\subsection{Statistical Analysis}

All the experiments were conducted in triplicates. Analysis of variance (ANOVA) was performed and significant differences in mean values were evaluated by Duncan ( $\mathrm{P}<0.05$ ) using SPSS version 16.0 (SPSS, Chicago, Illinois, USA).

\section{Results and Discussion}

\subsection{Proximate Analysis}

Results for the proximate composition of the doum fruit are presented in Table 1 . No significant differences $(\mathrm{p}<0.05)$ were observed in moisture content and dry matter among the three samples $(6 \%, 5.5 \%$ and $5.8 \%$ of epicarp, flesh and pitted fruit respectively) for moisture content, while for dry matter (94\%, $94.3 \%$ and $94.2 \%$ for epicarp, flesh and pitted fruit respectively). The oil content

of the fruit was found to be low. Results showed that there was a significant difference in the lipid content of the flesh $0.92 \%$ compared with the epicarp $0.39 \%$ and pitted doum fruit $0.6 \%(p<0.05)$. The results on the lipid content of the flesh sample are in agreement with the result $0.95 \%$ of Doum pulp(Hyphaene thebaica ) reported by [20] and $0.8 \%$ of African Doum Palm Fruit Mesocarp, (Hyphaene compressa) reported by [21]. On the other hand, no significant differences $(\mathrm{p}<0.05)$ were observed in protein content of the three samples $(2.4 \%, 2.17 \%$ and $2.32 \%$ of exocarp, flesh and pitted fruit respectively). However, the protein content of the flesh $(2.17 \%)$ was found to be more than the value $0.01 \%$ obtained in doum pulp (Hyphaene thebaica) as reported by [20]. Other researchers for example Bonde and Hoebeke found higher protein content 9.26\%, 3.8\% for Hyphaene dichotoma (young fruit) and (Hyphaene compressa) respectively[22,21]. These differences might be attributed to the species diversity, regional climate differences and postharvest treatments. Results also showed that there was a significant difference $(p<0.05)$ in ash content of different samples. Flesh ash content registered as the highest $6.64 \%$ which is less than the result $8.1 \%$ reported by [20] followed by pitted fruit $5.9 \%$ while the ash content of the epicarp was $4 \%$ which was the lowest in the three samples. Results also on fibre content showed significant difference $(p<0.05)$ with the epicarp having the higher amount (43.04\%), compared to pitted fruit (19.77\%) and flesh (12.27\%). The high fiber content of doum fruit is suggesting as a potential to be used in the formulation of bakery products to enrich their texture, flavor and nutritional value, beside its great contribution to the health and wellbeing of humankind by preventing the gastrointestinal problems such as constipation and therefore it is regarded as a natural anti colon cancer [23]. The carbohydrate content in the flesh presented the highest among the three samples followed by pitted fruit and the epicarp (72.5\%, 65.61\% and $44.17 \%$, respectively). This high carbohydrate content in doum fruit can be very helpful to many low income communities especially in developing countries as it can be used as a substitute for other high cost carbohydrate sources. Based on energy levels using the universally acceptable conversion factors of $4 \mathrm{kcal} / \mathrm{g}$ for carbohydrate and protein and $9 \mathrm{kcal} / \mathrm{g}$ for fats or lipids, it was found out that the different fruit components have higher energy values as evidenced by the values of $361.94 \mathrm{kcal} / 100 \mathrm{~g}$, $356.2 \mathrm{kcal} / 100 \mathrm{~g}$ and $356.04 \mathrm{kcal} / 100 \mathrm{~g}$ for epicarp, pitted fruit and flesh respectively. It is evident from energy values obtained that consumption of doum fruit can provide relevant needed energy level and address the energy related disease disorders in humans.

Table 1. Proximate composition of Epicarp, Flesh and pitted doum fruit (\%)

\begin{tabular}{cccc}
\hline Parameters & Epicarp & Flesh & pitted fruit \\
\hline Moisture & $6.00 \pm 0.20^{\mathrm{a}}$ & $5.50 \pm 0.43^{\mathrm{a}}$ & $5.80 \pm 0.20^{\mathrm{a}}$ \\
Solid content & $94.00 \pm 0.20^{\mathrm{a}}$ & $94.33 \pm 0.15^{\mathrm{a}}$ & $94.2 \pm 0.20^{\mathrm{a}}$ \\
Fat & $0.39 \pm 0.08^{\mathrm{c}}$ & $0.92 \pm 0.08^{\mathrm{a}}$ & $0.60 \pm 0.07^{\mathrm{b}}$ \\
Protein & $2.40 \pm 0.20^{\mathrm{a}}$ & $2.17 \pm 0.14^{\mathrm{a}}$ & $2.32 \pm 0.09^{\mathrm{a}}$ \\
Ash & $4.00 \pm 0.36^{\mathrm{c}}$ & $6.64 \pm 0.06^{\mathrm{a}}$ & $5.90 \pm 0.01^{\mathrm{b}}$ \\
Fiber & $43.04 \pm 0.90^{\mathrm{a}}$ & $12.27 \pm 0.09^{\mathrm{c}}$ & $19.77 \pm .08^{\mathrm{b}}$ \\
Carbohydrate & $44.17 \pm 1.28^{\mathrm{c}}$ & $72.50 \pm 0.50^{\mathrm{a}}$ & $65.61 \pm 0.04^{\mathrm{b}}$ \\
Energy (Kcal) & $361.94 \pm 1.09^{\mathrm{a}}$ & $356.04 \pm 1.69^{\mathrm{b}}$ & $356.2 \pm 1.36^{\mathrm{b}}$ \\
\hline The results represent the mean \pm standard deviation of the analysis \\
performed in triplicate. \\
Data with different superscript letters in the same row were significantly \\
different (P <0.05).
\end{tabular}




\subsection{Mineral Elements Composition}

Table 2. Mineral elements (mg/100 g) of Epicarp, Flesh and pitted doum fruit

\begin{tabular}{cccc}
\hline $\begin{array}{c}\text { Mineral } \\
\text { elements }\end{array}$ & Epicarp & Flesh & Pitted fruit \\
\hline $\mathrm{K}$ & $806.20 \pm 0.666^{\mathrm{c}}$ & $2947.60 \pm 2.695^{\mathrm{a}}$ & $1590.00 \pm 2.179^{\mathrm{b}}$ \\
$\mathrm{Na}$ & $364.70 \pm 1.188^{\mathrm{a}}$ & $184.35 \pm 1.408^{\mathrm{b}}$ & $226.10 \pm 1.249^{\mathrm{c}}$ \\
$\mathrm{Ca}$ & $284.00 \pm 1.050^{\mathrm{a}}$ & $254.80 \pm 1.311^{\mathrm{b}}$ & $256.60 \pm 1.015^{\mathrm{b}}$ \\
$\mathrm{Mg}$ & $94.87 \pm 0.967^{\mathrm{c}}$ & $185.62 \pm 1.233^{\mathrm{a}}$ & $133.40 \pm 1.153^{\mathrm{b}}$ \\
$\mathrm{P}$ & $102.30 \pm 0.775^{\mathrm{c}}$ & $154.60 \pm 1.101^{\mathrm{a}}$ & $128.00 \pm 0.548^{\mathrm{b}}$ \\
$\mathrm{Fe}$ & $12.18 \pm 0.666^{\mathrm{a}}$ & $3.52 \pm 0.292^{\mathrm{c}}$ & $6.86 \pm 0.240^{\mathrm{b}}$ \\
$\mathrm{Zn}$ & $6.74 \pm 0.473^{\mathrm{a}}$ & $0.77 \pm 0.082^{\mathrm{c}}$ & $4.40 \pm 0.265^{\mathrm{b}}$ \\
$\mathrm{Cu}$ & $1.98 \pm 0.108^{\mathrm{a}}$ & $0.41 \pm 0.026^{\mathrm{c}}$ & $1.77 \pm 0.067^{\mathrm{b}}$ \\
$\mathrm{Mn}$ & $0.75 \pm 0.082^{\mathrm{a}}$ & $0.34 \pm 0.036^{\mathrm{c}}$ & $0.57 \pm 0.072^{\mathrm{b}}$ \\
$\mathrm{Ni}$ & $0.62 \pm 0.092^{\mathrm{a}}$ & $0.33 \pm 0.053^{\mathrm{b}}$ & $0.45 \pm 0.062^{\mathrm{b}}$ \\
$\mathrm{Co}$ & $0.17 \pm 0.026^{\mathrm{a}}$ & $0.12 \pm 0.017^{\mathrm{b}}$ & $0.15 \pm 0.020^{\mathrm{ab}}$ \\
$\mathrm{Pb}$ & $0.0073 \pm 0.0005^{\mathrm{a}}$ & $0.0037 \pm 0.0004^{\mathrm{c}}$ & $0.0054 \pm 0.0006^{\mathrm{b}}$ \\
$\mathrm{Cd}$ & $0.0039 \pm 0.0004^{\mathrm{a}}$ & $0.0017 \pm 0.0002^{\mathrm{b}}$ & $0.0021 \pm 0.0003^{\mathrm{b}}$ \\
$\mathrm{Na} / \mathrm{K}$ & 0.452 & 0.063 & 0.142 \\
$\mathrm{Ca} / \mathrm{P}$ & 2.776 & 1.648 & 2.005 \\
\hline $\mathrm{Th}$ & $\mathrm{C}$ & &
\end{tabular}

The results represent the mean \pm standard deviation of the analysis performed in triplicate.

Data with different superscript letters in the same row were significantly different $(\mathrm{P}<0.05)$.

Results for mineral composition of doum fruit samples are presented in Table 2. Significant differences $(\mathrm{p}<0.05)$ in the fruit components were observed for potassium, sodium, magnesium, phosphorus, iron, zinc, copper and manganese). However, no significant difference was observed $(p<0.05)$ in calcium content of flesh $(254.8$ $\mathrm{mg} / 100 \mathrm{~g}$ ) and pitted fruit $(256.6 \mathrm{mg} / 100 \mathrm{~g})$, while each of them retained a significant variation with epicarp content (284 mg/100 g). From the results, it is clear that doum fruit contains higher amounts of essential minerals which in most instances exceed the recommended dietary allowance (RDA), thus may keep the balances and ratios between those in need. It has been reported that $\mathrm{Na} / \mathrm{K}$ ratio less than one has a great importance in the body for the control of high blood pressure [24]. A food or feed source is considered good if the $\mathrm{Ca} / \mathrm{P}$ ratio is above one and poor if the ratio is less than 0.5 [25]. Since the result of this study gives $\mathrm{Ca} / \mathrm{P}$ ratio more than one (epicarp (2.776), flesh (1.648) and pitted fruit (2.005)) and $\mathrm{Na} / \mathrm{k}$ less than one (epicarp (0.452), flesh (0.063) and pitted fruit (0.142)), it showed that the doum fruit could have a potential to control the hypertension. Magnesium content was observed to be higher in flesh sample (185.62 mg/100 g) followed by pitted fruit $(133.4 \mathrm{mg} / 100 \mathrm{~g})$ and the lowest in epicarp sample $(94.87 \mathrm{mg} / 100 \mathrm{~g})$. Magnesium is required for the activation of more than 300 enzymes in the body. It's also useful for the utilization of some vitamins and minerals and required for normal function and structure of the arteries, heart, kidney, bone and for the neuromuscular system [26]. The other minerals like copper, iron, manganese and zinc have also been reported to be essential for preventing deficiency diseases. Copper is a very important component of a number of enzymes that reduce molecular oxygen as well as being part of numerous enzymes involved in metabolizing substances such as histidine, serotonin, epinephrine, norepinephrine and dopamine. Iron is a required factor of hemoglobin, which transports oxygen to body tissues. It is also a component of numerous other proteins and enzymes. Manganese is an essential constituent in numerous enzymes involved in bone formation and in metabolism of amino acids, lipids and carbohydrates. Zinc is an essential module or element in nearly 100 enzymes [27]. On the other hand, nickel and cobalt contents in the epicarp were found to be significantly different $(p<0.05)$ from the values in flesh while there was no significant difference in nickel and cobalt in contents in pitted and flesh samples as well as for pitted and epicarp samples in cobalt content. Although, the content of both $\mathrm{Pb}$ (Lead) and Cd (cadmium) was found to be very low, but there was a considerable difference in the $\mathrm{Pb}$ content of all samples. The highest was observed in epicarp followed by pitted fruit and finally flesh as the lowest among the three samples. On the other hand, the Cd content of epicarp resulted into high difference from the rest of samples (flesh and pitted fruit). Generally the minerals content were higher in epicarp followed by pitted fruit and flesh samples; however the flesh sample showed the highest content of $\mathrm{K}$, $\mathrm{Mg}$, and $\mathrm{P}$ among the three samples. The results demonstrated that doum fruit is a good source of essential minerals and therefore can promote the health and well being of individuals.

\subsection{Vitamin Content}

The results for vitamin content of doum fruit samples are presented in Table 3 . The results showed that there was significant difference $(p<0.05)$ in vitamin content in different components of doum fruit. Ascorbic acid (vitamin C) content was found to be higher in flesh followed by pitted fruit and not detected in epicarp sample. Vitamin B-complex in the different fruit components was highest in the epicarp followed by pitted fruit and least in flesh sample. Pyridoxine (vitamin B6) was the most dominant among the B-complex vitamins in doum fruit. However, no significant difference was observed in pyridoxine content of the epicarp and pitted fruit (13.6 and 13.43 respectively). Generally, doum fruit content of Pyridoxine and Riboflavin (vitamin B2) were higher followed by thiamin (vitamin B1) and Folic acid (vitamin B9) compared to Niacin (vitamin B3) and Vitamin C.

A deficiency in a single B-complex vitamin can stunt growth and produce significant adverse effects. Thiamin is absolutely essential for several body functions, which can be summarized under two main categories: Energy metabolism and Nervous system, Thiamine deficiency leads to reduction in growth, hair loss, weakness, anorexia and depression. [28,29]. Riboflavin is essential in many biological functions in the body for example, it acts as a coenzyme in the breakdown of macronutrients, helps fatty acid reduction, assist choline catabolism, necessary for catabolism of nutrients in the liver, assists eye and skin maintenance alongside with many other functions [30]. With respect to niacin, almost 200 enzymes require NAD and NADP to function. As a reflection of niacin importance, NAD helps glycolysis, oxidation of pyruvate, acetyl CoA by the Kreb cycle, and fatty acids. NADP assists with fatty acid synthesis, cholesterols and steroid synthesis, oxidation of glutamate, and DNA synthesis [29]. Pyridoxine is essential for cellular functions and growth due to its involvement in important metabolic reactions [31]. Folic acid helps in the metabolism of several amino acids such as histidine, glycine, serine and methionine as well as being essential for cell division, production of DNA and RNA, and assists the prevention of changes in DNA, which may lead to cancer [31]. The higher values of vitamin B-complex obtained in this study signifies that 
promoting consumption of doum fruit can help in many body functions and thereby contributing to good health.

Table 3. vitamin composition (mg/100 g) of Epicarp, Flesh and pitted doum fruit

\begin{tabular}{cccc}
\hline Parameters & Epicarp & Flesh & Pitted fruit \\
\hline Vitamin C & ND & $1.12 \pm 0.036^{\mathrm{a}}$ & $0.57 \pm 0.026^{\mathrm{b}}$ \\
Thiamin (Vit. B1) & $9.20 \pm 0.108^{\mathrm{a}}$ & $1.01 \pm 0.006^{\mathrm{c}}$ & $3.8 \pm 0.089^{\mathrm{b}}$ \\
Riboflavin (Vit. B2) & $6.90 \pm 0.116^{\mathrm{a}}$ & $3.30 \pm 0.072^{\mathrm{c}}$ & $5.40 \pm 0.197^{\mathrm{b}}$ \\
Niacin (Vit. B3 or PP) & $3.60 \pm 0.096^{\mathrm{a}}$ & $1.74 \pm 0.066^{\mathrm{c}}$ & $2.94 \pm 0.098^{\mathrm{b}}$ \\
Pyridoxine (Vit. B6 ) & $13.60 \pm 0.121^{\mathrm{a}}$ & $12.22 \pm 0.177^{\mathrm{b}}$ & $13.43 \pm 0.140^{\mathrm{a}}$ \\
Folic acid (Vit. B9) & $8.43 \pm 0.127^{\mathrm{a}}$ & $0.99 \pm 0.066^{\mathrm{c}}$ & $1.37 \pm 0.075^{\mathrm{b}}$ \\
\hline The results represent the mean \pm standard deviation of the analysis \\
performed in triplicate. \\
Data with different superscript letters in the same row were significantly \\
different (P <0.05). \\
ND: Not detected.
\end{tabular}

\subsection{Monosaccharide and Total Sugar Content}

Results for the monosaccharides and total sugar content are presented in Table 4. There were significant differences $(p<0.05)$ in some monosaccharide content (glucose and fructose) of doum fruit samples. The highest content of Glucose was detected in flesh sample followed by pitted fruit and epicarp (406, 349 and $240 \mathrm{mg} / 100 \mathrm{~g}$ respectively). Fructose content in epicarp, pitted fruit and flesh was found to be $112.3,47.6$ and $43.33 \mathrm{mg} / 100 \mathrm{~g}$ respectively. On the other hand, no major differences were observed in the xylose content of epicarp and flesh as values of 0.6 and $0.7 \mathrm{mg} / 100 \mathrm{~g}$ respectively were obtained. The arabinose content obtained in different fruit components was low. The epicarp contained $0.8 \mathrm{mg} / 100 \mathrm{~g}$ arabinose while it was not detected in the other parts. The high value of some monosaccharides obtained in this study signifies that promoting consumption of doum fruit. In general, total monosaccharide content was higher in flesh sample followed by pitted fruit and it was lowest in epicarp sample.

Table 4. Monosaccharides (mg/100 g) of Epicarp, Flesh and pitted doum fruit

\begin{tabular}{cccc}
\hline Monosaccharides & Epicarp & Flesh & Pitted fruit \\
\hline Arabinose & $0.80 \pm 0.056^{\mathrm{a}}$ & ND & ND \\
Glucose & $240.00 \pm 1.730^{\mathrm{c}}$ & $406.00 \pm 1.956^{\mathrm{a}}$ & $349.00 \pm 1.740^{\mathrm{b}}$ \\
Xylose & $0.60 \pm 0.044^{\mathrm{b}}$ & $0.70 \pm 0.114^{\mathrm{b}}$ & $0.86 \pm 0.044^{\mathrm{a}}$ \\
fructose & $112.30 \pm 0.794^{\mathrm{a}}$ & $43.33 \pm 0.929^{\mathrm{b}}$ & $47.6 \pm 1.060^{\mathrm{c}}$ \\
Total & $353.70 \pm 2.468^{\mathrm{c}}$ & $450.30 \pm 2.429^{\mathrm{a}}$ & $397.46 \pm 2.815^{\mathrm{b}}$ \\
\hline The results represent the mean \pm standard deviation of the analysis \\
performed in triplicate. \\
Data with different superscript letters in the same row were significantly \\
different (P <0.05). \\
ND: Not detected.
\end{tabular}

\subsection{Physical Properties}

\subsubsection{Colour and Bulk Density}

The results for the colour measurements by hunter color values $\left(\mathrm{L}^{*}, \mathrm{a}^{*}, \mathrm{~b}^{*}\right)$ and bulk density of different samples are presented in Table 5. Significant differences $(\mathrm{p}<0.05)$ were observed between the different color parameters, the " $\mathrm{L}$ *" values for epicarp, flesh and pitted fruit were 68.44, 80.81 , and 74.44 respectively. $\mathrm{a}^{*}$ and $\mathrm{b}^{*}$ values of three samples varied between 5.26 to 17.49 and 11.02 to 19.84 . The results showed that the flesh tended to be lighter (high value of $\mathrm{L}^{*}$ ) and less reddish (low a* value) followed by pitted fruit sample, whereas epicarp sample was darker (lowest $\mathrm{L}^{*}$ value), with highest $\mathrm{a}^{*}$ and $\mathrm{b}^{*}$ value (more reddish yellow), that may be due to the high content of carbohydrate in flesh sample. The total color difference $(\Delta \mathrm{E})$ of the samples ranged from 26.71 to 37.42 . The difference in the color characteristics of different flours might be attributed to differences in colored pigments of the samples, which in turn depends on the botanical origin of the plant and also to the composition of the flour [32]. In this study the doum fruit samples retained their original colors after sun drying and milling.

Significant differences $(p<0.05)$ were also observed for bulk density among the different flours from doum fruit samples, the values obtained were $0.73,0.95$ and 0.78 for epicarp, flesh and pitted fruit respectively. Bulk density is a reflection of the load that sample can carry if allowed to rest directly on another and the bulk density of flour could also be used to determine its packaging requirements [18].

Table 5. Color parameters and Bulk density (BD) of Doum (Hyphaene thebaica) fruit samples

\begin{tabular}{cccc}
\hline & Epicarp & Flesh & Pitted fruit \\
\hline $\boldsymbol{L}^{*}$ & $68.44 \pm 0.079^{\mathrm{c}}$ & $80.81 \pm 0.055^{\mathrm{a}}$ & $74.44 \pm 0.415^{\mathrm{b}}$ \\
$\boldsymbol{a}^{*}$ & $11.02 \pm 0.068^{\mathrm{a}}$ & $5.26 \pm 0.015^{\mathrm{c}}$ & $6.69 \pm 0.045^{\mathrm{b}}$ \\
$\boldsymbol{b}^{*}$ & $17.49 \pm 0.080^{\mathrm{c}}$ & $18.14 \pm 0.025^{\mathrm{b}}$ & $19.84 \pm .015^{\mathrm{a}}$ \\
$\boldsymbol{\Delta}^{*}$ & $37.42 \pm 0.806^{\mathrm{a}}$ & $26.71 \pm 0.700^{\mathrm{c}}$ & $32.78 \pm 0.701^{\mathrm{b}}$ \\
$\mathbf{B D}(\mathbf{g} / \mathbf{m l})$ & $0.73 \pm 0.006^{\mathrm{c}}$ & $0.95 \pm 0.015^{\mathrm{a}}$ & $0.78 \pm 0.021^{\mathrm{b}}$ \\
\hline
\end{tabular}

The results represent the mean \pm standard deviation of the analysis performed in triplicate.

Data with different superscript letters in the same row were significantly different $(\mathrm{P}<0.05)$.

\subsection{Functional Properties}

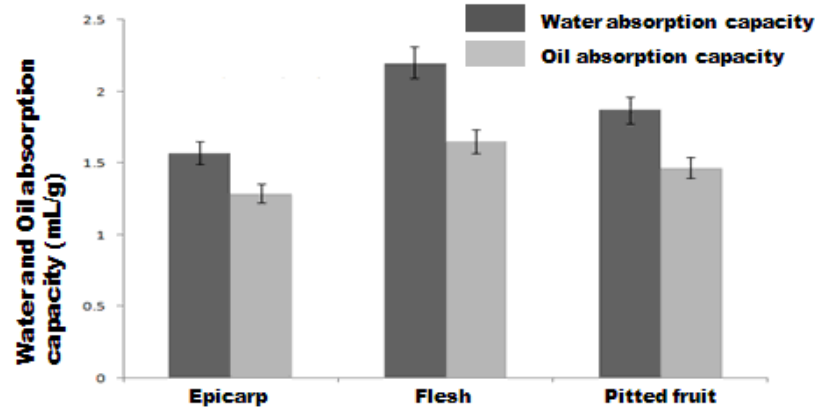

Figure 1. water and oil absorption capacity $(\mathrm{mL} / \mathrm{g})$ of Doum (Hyphaene thebaica) fruit samples

The results of water absorption capacity (WAC) and oil absorption capacity (OAC) for the three samples are presented in Figure 1. The results showed that the flesh had the highest WAC $(2.2 \mathrm{ml} / \mathrm{g})$, followed by pitted fruit $(1.87 \mathrm{ml} / \mathrm{g})$ while the lowest was observed in epicarp sample $(1.57 \mathrm{ml} / \mathrm{g})$. Water absorption characteristics represent the ability of a product to associate with water under conditions where water is limiting [33]. The high WAC of flesh could be attributed to the presence of higher amount of carbohydrates in this sample. The OAC of different samples ranged from 1.29 to $1.65 \mathrm{ml} / \mathrm{g}$. OAC is of great importance from an industrial viewpoint, since it reflects emulsifying capacity. The ability of flours to absorb and retain water and/or oil may help to improve binding of the structure, enhance flavor retention and improve the mouthfeel [18]. The results of wettability capacity (WC) and gelatinization point(GP) of epicarp, flesh and pitted fruit of doum samples are presented in Figure 2. Results showed that the WC was highest in flesh sample followed by pitted fruit and lowest in epicarp sample as shown by the following values of $27 \mathrm{sec}, 17 \mathrm{sec}$ 
and 11 sec respectively. Figure 2 (a). The GP showed decrease in flesh sample followed by pitted fruit and was the highest in epicarp sample, $\left(90^{\circ} \mathrm{C}, 94^{\circ} \mathrm{C}\right.$ and $98^{\circ} \mathrm{C}$ respectively) Figure 2 (b). The low GP of flesh sample
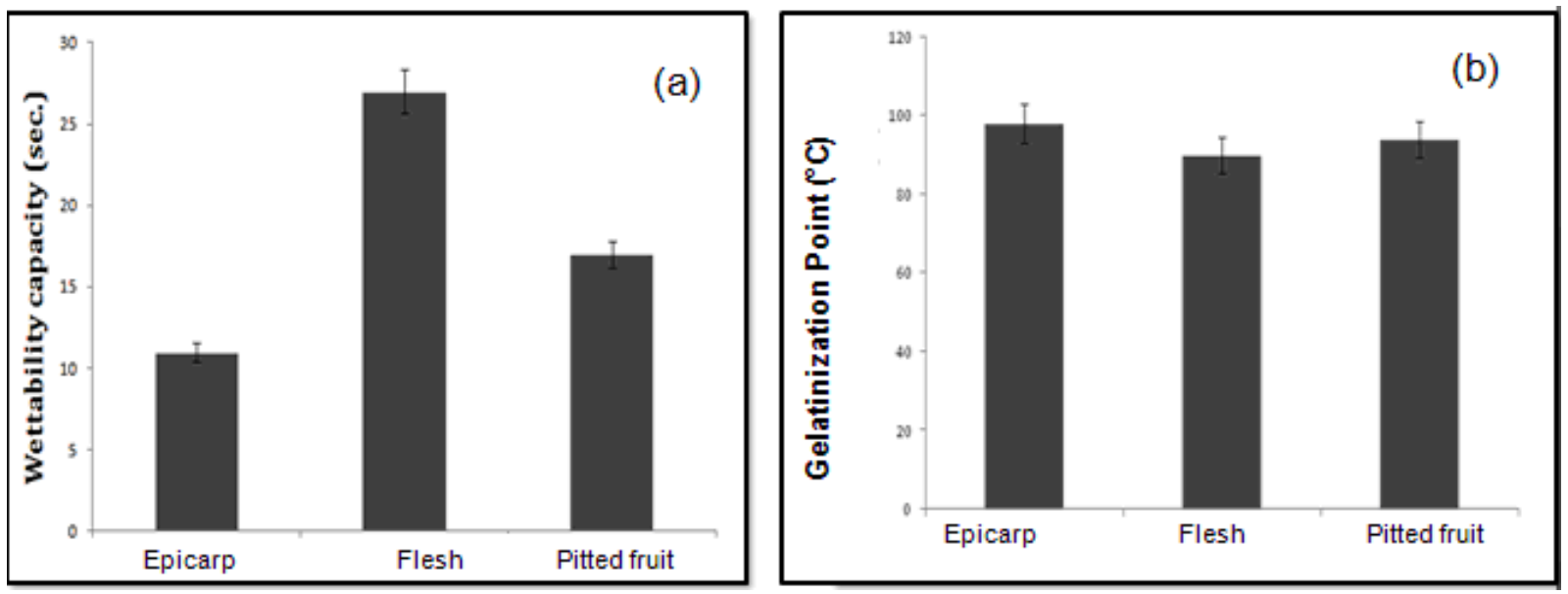

Figure 2. (a) Wettability capacity (sec) and (b) gelatinization point ${ }^{\circ} \mathrm{C}$ of Doum (Hyphaene thebaica) fruit samples

\section{Conclusion}

The findings of this study show that physicochemical, nutritional and functional properties differ significantly in the epicarp, flesh and pitted sample of doum fruit (Hyphaene thebaica). The results show that doum fruit is a good source of essential minerals such as potassium, sodium, calcium, magnesium and phosphorus. Furthermore, doum fruit has shown to provide essential Bcomplex vitamins, carbohydrate and fibers essential for good nutrition. The results have also demonstrated that the doum fruit possesses good functional properties which can be used for various important applications in food industry. It can therefore be concluded that the doum fruit provides essential nutrients and possesses important functional properties which if well exploited can help to address many food related problems like diabetic and hypertensive patients.

\section{Acknowledgement}

This work was supported by grants from the Natural Sciences Foundation of China (31171724), National Key Technology R\&D Program for the 12th five-year plan (2012BAD33B05) and the Specialized Research Fund for the Doctoral Program of Higher Education (SRFDP 20130093110008).

\section{References}

[1] Fletcher, R. (1997). Listing of useful plants of the world. Australian New crops http://www.newcrops.uq.edu.au/listing/hyphaenethebaica

[2] Orwa, C., Mutua, A., Kindt, R., Jamnadass, R., Simons, A. (2009). "Agroforestree database: a tree reference and selection guide version 4.0". Url: http://www.Worldagroforestry.org/af/treedb/ (Accessed on 15 February, 2011)

[3] Doren, E. T. (1997). Vegetable ivory and other palm nuts/seeds as an art/craft medium. Journal of the International Palm Society (renamed as Palms since 1999), 41 (4), 18-25.

[4] Kamis, A. B., Modu, S., Zanna, H., \& Oniyangi, T. A. (2003) Preliminary biochemical and haematological effects of aqueous might be attributed to the high carbohydrate content of flesh compared to epicarp which has a higher GP and low carbohydrate content. suspension of pulp of hyphaene thebaica (l) mart in rats. Biokemistri. 13 (1): 1-7.

[5] Hsu, B., Coupar, I. M., Ng, K. (2006). Antioxidant activity of hot water extracts from the fruit of the Doum palm, (Hyphaene thebaica) Food Chemistry, 98 (2), 317-328.

[6] Faten, M. A. E. (2009). Antioxidant and anticancer activities of doum fruit extract (Hyphaene thebaica). African Journal of Pure and Applied Chemistry, 3 (10), 197-201.

[7] Carter. J (1993). Dietary fiber guide. Cereal Foods World, 38 (10): 755-759.

[8] Dosurnu, O.O., Nwosu, F.O, Nwogu, C.D (2006). Antimicrobial studies and Phtochemical Screening of extracts of Hyphaene thebaica (Linn) Mart fruits. International Journal of Tropical Medicine 1 (4): 186-189.

[9] Mason, J. B. (2007). Vitamins, trace minerals, and other micronutrients. Goldman L, Ausiello D. Cecil Textbook of Medicine, 225, p (e 225-1).

[10] Latham, M. C. (1997). Human nutrition in the developing world (No. 29). Food \& Agriculture Org.

[11] Nur Dirim, S. (2012). Determination of the effect of freeze drying process on the production of pumpkin (Cucurbita moschata) puree powder and the powder properties. GIDA/ The Journal of FOOD, 37 (4).

[12] Association of Official Analytical Chemists International. Official Methods of Analysis of the Association of Official Analytical Chemists International 17th edn. (2000). Association of Official Analytical Chemists International, Arlington, VA, USA.

[13] Pereira, J. A., Oliveira, I., Sousa, A., Ferreira, I. C., Bento, A., Estevinho, L. (2008) Bioactive properties and chemical composition of six walnut (Juglans regiaL.) cultivars. Food Chem Toxicol 46: 2103-2111.

[14] AOAC (1995). Official Methods of Analysis of the AOAC international, $16^{\text {th }}$ ed. Method 970.12. Association of Official Analytical Chemists International. Washington, DC, USA.

[15] Ranganna S. (1986). Handbook of Analysis and Quality Control for Fruit and Vegetable Products. Tata McGraw-Hill Publishing Company, New Delhi, India. pp. 124-125.

[16] Papadoyannis, I. N., Tsioni, G. K., Samanidou, V. F. (1997). Simultaneous determination of nine water and fat soluble vitamins after SPE separation and RP-HPLC analysis in pharmaceutical preparations and biological fluids. Journal of liquid chromatography \& related technologies, 20 (19), 3203-3231.

[17] Mopper, K.., Schultz, C. A., Chevolot, L., Germain, C., Revuelta, R., Dawson, R. (1992). Determination of sugars in unconcentrated seawater and other natural waters by liquid chromatography and pulsed amperometric detection. Environmental science \& technology, 26 (1), 133-138.

[18] Kaur, M., Kaushal, P., \& Sandhu, K. S. Studies on physicochemical and pasting properties of Taro (Colocasia esculenta L.) flour in comparison with a cereal, tuber and legume 
flour. Journal of Food Science and Technology. 2013; 50 (1): 94100.

[19] Onwuka, G. I. (2005). Food analysis and instrumentation: theory and practice. Naphathali prints, Nigeria, 95-96.

[20] Nwosu, F. O.*, Dosumu, O. O., Okocha, J. O. C. (2008). The potential of Terminalia catappa (Almond) and Hyphaene thebaica (Dum palm) fruits as raw materials for livestock feed. African Journal of Biotechnology Vol. 7 (24), pp. 4576-4580.

[21] Hoebeke, P. 1989. The doum palm (Hyphaene compressa) as biological resource in Turkana District, Kenya. M.Sc. thesis, University of Trondheim, Norway.

[22] Bonde, S. D., Agate, V. V., Kulkarni, D. K. (1990). Nutritional composition of the fruits of doum palms (Hyphaene) from the west coast of India. Principes, 34 (1), 21-23.

[23] Coimbra, M. C., Jorge, N. (2011). Proximate composition of guariroba (Syagrus oleracea), jerivá (Syagrus romanzoffiana) and macaúba (Acrocomia aculeata) palm fruits, Food Research International (44) 2139-2142

[24] Aremu, M. O., Olaofe, O., Akintayo, T. E. (2006). A comparative study on the chemical and amino acid composition of some Nigerian under-utilized legume flours. Pak. J. Nutr., 5: 34-38.

[25] Nieman, D. C. Butterworth DE, Nieman CN (1992). Nutrition, Wmc Brown Publishers. Dubugye, USA, 237-312.

[26] Durlach J. (1988). Magnesium in clinical practice. Libbey Eurotext, London, Paris. p. 360
[27] Trumbo, P., Yates, A. A., Schlicker, S., \& Poos, M. (2001). Dietary reference intakes: vitamin A, vitamin $\mathrm{K}$, arsenic, boron, chromium, copper, iodine, iron, manganese, molybdenum, nickel, silicon, vanadium, and zinc. Journal of the American Dietetic Association, 101 (3), 294-301.

[28] Riordan, H. D., Mikirova, N., Taylor, P. R., Feldkamp, C. A., Casciari, J. J. (2012). The Effects of a Primary Nutritional Deficiency (Vitamin B Study). Food \& Nutrition Sciences, 3 (9).

[29] Rucker, R., Suttie, J., McCormick, D., Machlin, L. (2001): Handbook of Vitamins, 3rd Edition, New York: Marcel Dekker.

[30] McCormick D. B. (1999). "Modern Nutrition in Health and Disease,” ed. By Shils M. E., Olson J. A., Shike M., Ross A. C., Williams and Wilkins Press, Baltimore, pp. 391-399.

[31] Bender, D. A. (2003). Nutritional biochemistry of the vitamins. Cambridge university press.

[32] Njintang, Y. N., Scher, J., Mbofung, C. M. F. (2008). Physicochemical, thermal properties and micro structure of six varieties of taro (Colocasia esculentaL. Schott) flours and starches. Journal of Food Engineering 86 (2): 294-305.

[33] Singh N., Kaur M., Sandhu, K.S,and Guraya, H.S. (2004). Physicochemical, thermal, morphological and pasting properties of starches from some Indian black gram (Phaseolus mungoL.) cultivars. Starch- Stärke, 56 (11), 535-544. 